\title{
The Renal Hemodynamic Effects of Ibuprofen in the Newborn Rabbit
}

\author{
NADA SALAME CHAMAA, DOLORES MOSIG, ALFRED DRUKKER, AND \\ JEAN-PIERRE GUIGNARD \\ Division of Pediatric Nephrology and Department of Pediatrics, University Medical Center, \\ Lausanne, Switzerland
}

\begin{tabular}{|c|c|}
\hline \multicolumn{2}{|c|}{ ABSTRACT } \\
\hline $\begin{array}{l}\text { In early childhood, nonsteroidal anti-inflammatory drugs are } \\
\text { mainly used to either prevent or treat premature labor of the } \\
\text { mother and patent ductus arteriosus of the newborn infant. The } \\
\text { most frequently used prostaglandin-synthesis inhibitor is indo- } \\
\text { methacin. Fetuses exposed to indomethacin in utero have been } \\
\text { born with renal developmental defects, and in both the unborn } \\
\text { child and the term and premature newborn this drug may com- } \\
\text { promise renal glomerular function. The latter has in the past also } \\
\text { been observed when i.v. indomethacin or i.v. acetylsalicylic acid } \\
\text { (aspirin) were administered to newborn rabbits. The present } \\
\text { experiments were designed to evaluate whether ibuprofen has } \\
\text { less renal side effects than indomethacin, as claimed. Three } \\
\text { groups of anesthetized, ventilated, normoxemic neonatal rabbits } \\
\text { were infused with increasing doses of ibuprofen (0.02, 0.2, } 2.0 \\
\text { mg/kg body weight) and the following renal parameters were } \\
\text { measured: urine volume, urinary sodium excretion, GFR, and } \\
\text { renal plasma flow. Renal blood flow, filtration fraction, and the } \\
\text { renal vascular resistance were calculated according to standard } \\
\text { formulae. Intravenous ibuprofen caused a dose-dependent, sig- } \\
\text { nificant reduction in urine volume, GFR, and renal blood flow } \\
\text { with a fall in filtration fraction in the animals receiving the } \\
\text { highest dose of ibuprofen ( } 2 \text { mg/kg body weight). There was a } \\
\text { very steep rise in renal vascular resistance. Urinary sodium } \\
\text { excretion decreased. These experiments in neonatal rabbits }\end{array}$ & $\begin{array}{l}\text { clearly show that acute i.v. doses of ibuprofen also have signif- } \\
\text { icant renal hemodynamic and functional side effects, not less } \\
\text { than seen previously with indomethacin. (Pediatr Res 48: 600- } \\
\text { 605, 2000) } \\
\text { ARF, acute renal failure } \\
\text { BW, body weight } \\
\text { Cin, CPAH, clearances of inulin and PAH, respectively } \\
\text { COX, cyclo-oxygenases } \\
\text { EPAH, extraction of para-amino-hippuric acid } \\
\text { FF, filtration fraction } \\
\text { HR, heart rate } \\
\text { Htc, hematocrit } \\
\text { MAP, mean arterial blood pressure } \\
\text { NSAID, nonsteroidal anti-inflammatory drugs } \\
\text { PAH, para-amino-hippuric acid } \\
\text { PDA, patent ductus arteriosus } \\
\text { PG, prostaglandin } \\
\text { RBF, renal blood flow } \\
\text { RPF, renal plasma flow } \\
\text { RVR, renal vascular resistance } \\
\text { UV, urine flow rate } \\
\text { UVNa, urinary excretion of sodium }\end{array}$ \\
\hline
\end{tabular}

Since the mid-1970s, indomethacin has been used for the prenatal and postnatal prevention and closure of PDA in term and premature infants $(1,2)$. This nonspecific PG inhibitor, as well as the newer selective COX inhibitors, is also used during pregnancy as a tocolytic agent, to prevent and treat premature labor and/or polyhydramnios $(3,4)$. The curative effects of these NSAID are accompanied by various side effects, including hemodynamic changes in many organ systems. In the newborn, particular attention has been given to the cerebral,

Received February 14, 2000; accepted July 19, 2000.

Correspondence and reprint requests: Jean-Pierre Guignard, M.D., Unité de Néphrologie, Département de Pédiatrie, Centre Hospitalier Universitaire Vaudois (CHUV), CH1011 Lausanne, Switzerland.

This study was supported by a grant (no. 3200-052463.97/1) from the Swiss National Science Foundation. mesenteric, and renal circulations $(5,6)$. The renal side effects of fetal or neonatal exposure to indomethacin, the most frequently used NSAID, relate to three closely interrelated aspects. Firstly, it has recently become clear that COX are essential for normal renal morphogenesis and maturation (79). Prolonged intrauterine COX inhibition may induce clinically important changes in renal maturation, including renal dysplasia or dysgenesis and cortical (glomerular) development. Secondly, the intrauterine exposure of the fetus to indomethacin can functionally impair the renal circulation of the fetus, causing a very significant decrease in GFR with oligoanuria and consequently oligohydramnios (10-12). Thirdly, when indomethacin is given postnatally in a dose that generally will induce closure of a hemodynamically significant PDA (three i.v. doses of $0.2 \mathrm{mg} / \mathrm{kg} \mathrm{BW} \mathrm{q} 12 \mathrm{~h}$ ) renal function is often 
compromised, even to the degree of (generally reversible) oliguric ARF (13-15). The same has been found under experimental conditions. When i.v. indomethacin or i.v. acetylsalicylic acid (aspirin) was given to anesthetized, ventilated newborn rabbits, a rise in renal vascular resistance (RVR) was found with a very significant reduction in RBF, GFR, and UV $(16,17)$.

It has been claimed that ibuprofen, another prominent NSAID, has less renal side effects in the neonatal period than indomethacin (18-20). It was the aim of the present experiments to verify this claim. We therefore studied the renal hemodynamic effects of ibuprofen in the newborn rabbit, a well-established animal model for the study of neonatal renal function, with great similarities to the developing kidney of the human premature infant (21).

\section{METHODS}

Animal experiments. A total of 42 newborn New Zealand white rabbits, $5-8 \mathrm{~d}$ of age (mean \pm SEM: $6.2 \pm 0.2$ ), weighing $77-135 \mathrm{~g}(106 \pm 2)$, were studied. The animals were born in our own animal facilities by spontaneous vaginal delivery and breast-fed. All animal studies were performed according to the instructions of the relevant review boards of the Centre Hospitalier Universitaire Vaudois and the University of Lausanne. The rabbits were anesthetized with $25 \mathrm{mg} / \mathrm{kg}$ BW of i.p. sodium-pentobarbital followed by subsequent small i.v doses, as required. After tracheostomy, the animals were artificially ventilated (Harvard 683 Rodent Ventilator, Millis, MA, U.S.A.). The respiratory rate was kept constant at 40 breaths/min and tidal volume was adjusted for age and weight. Body temperature, recorded by an intraesophageal thermometer (Medical Precision Thermometer DM 852, Ellab, Copenhagen, Denmark), was kept constant at approximately $39^{\circ} \mathrm{C}$ with the use of a heating table and an infrared lamp. The right femoral vessels were catheterized with polyethylene catheters (PE 10) for solute infusion, arterial blood sampling, and monitoring of MAP and HR (Statham Transducers, recorded on a multichannel recorder, Gould Isolated Amplifier, model 134615-50, Gould Inc., Cleveland, OH, U.S.A.). The bladder was catheterized for urine sampling.

After surgery, the animals received an i.v. priming dose of inulin and PAH in a dose of 100 and $1.25 \mathrm{mg} / \mathrm{kg}$, respectively, for determination throughout the experiments of the Cin and CPAH, representing GFR and RPF, respectively. This was followed by the continuous infusion at a rate of $1 \mathrm{~mL} / 100 \mathrm{~g} \mathrm{BW} / \mathrm{h}$ of a solution containing per liter $50 \mathrm{~g}$ mannitol, $3 \mathrm{~g}$ inulin, $0.15 \mathrm{~g}$ PAH, $150 \mathrm{mmol}$ sodium, $105 \mathrm{mmol}$ chloride, $5 \mathrm{mmol}$ potassium, and $50 \mathrm{mmol}$ of sodium bicarbonate. The preparation of the animals took approximately $1 \mathrm{~h}$. After the surgical procedures, 90-min equilibration and 60-min control (C) periods were allowed. These periods were necessary to ensure that each animal could serve as its own control. The $\mathrm{C}$ period was used for two 30-min urine collections and $0.4 \mathrm{~mL}$ of blood was withdrawn at the midpoint between the two collections. The red blood cells were reconstituted in $0.4 \mathrm{~mL}$ of diluted human albumin and reinfused. Eighty microliters of plasma was used for immediate measurements of blood gases, Htc, and plasma protein levels. The remainder of the plasma was frozen for later determination of electrolytes and renal function tests.

Protocol. After the C period, an i.v. pulse of an ibuprofen solution with lysine was administered, and its effect was followed for another hour, the experimental period (E). During that period, two additional 30-min urine collections were made and blood was drawn at the midpoint of these collection. The red blood cells were again reinfused as outlined above. The protocol was the same for the three groups of animals, but differed in the dose of ibuprofen administered:

group I ( $n=11$; age $6 \pm 0.3 \mathrm{~d}$; wt $101.1 \pm 5.3 \mathrm{~g}$ ): $0.02 \mathrm{mg} / \mathrm{kg}$ BW of ibuprofen

group II ( $n=13$; age $6.2 \pm 0.2 \mathrm{~d}$; wt $111.4 \pm 3.5 \mathrm{~g}): 0.2 \mathrm{mg} / \mathrm{kg}$

BW of ibuprofen

group III $(n=10$; age $6.6 \pm 0.3 \mathrm{~d}$; wt $103.2 \pm 3.2 \mathrm{~g}): 2 \mathrm{mg} / \mathrm{kg}$ $\mathrm{BW}$ of ibuprofen

At the end of the experiments, the animals were killed with a lethal i.v. dose of sodium pentobarbital.

Vehicle control experiments (lysine). The commercially available ibuprofen for use in the laboratory (I4883; Sigma Chemical Co., St. Louis, MO, U.S.A.) comes in the form of a powder. The i.v. solution of the drug was prepared by dissolving $1 \mathrm{~g}$ of powdered ibuprofen with $800 \mathrm{mg}$ of lysine (base) in $100 \mathrm{~mL}$ of water for injection, as kindly suggested by Dr. B. van Overmeire and Dr. M. De Smet from the University Hospital, Antwerp, Belgium. This solution was, after appropriate dilution for the requested dose of ibuprofen, administered as an i.v. pulse $(20 \mu \mathrm{L} / \mathrm{kg} \mathrm{BW})$ to the animals of groups I-III. The animals of group I received $0.02 \mathrm{mg} / \mathrm{kg}$ ibuprofen together with $0.016 \mathrm{mg} / \mathrm{kg} \mathrm{BW}$ of lysine; this dose of lysine was 0.16 and $1.6 \mathrm{mg} / \mathrm{kg} \mathrm{BW}$ for the animals of groups II and III, which received 0.2 and $2 \mathrm{mg} / \mathrm{kg} \mathrm{BW}$ of ibuprofen, respectively. To exclude lysine toxicity, $800 \mathrm{mg}$ of lysine was dissolved in $100 \mathrm{~mL}$ of water for injection, obviously without addition of ibuprofen. This solution was diluted 100 -fold, and from that diluted solution $0.20 \mu \mathrm{L} / \mathrm{kg} \mathrm{BW}$ was infused to eight newborn rabbits (age $5.8 \pm 0.3 \mathrm{~d}$; weight $104.4 \pm 4.3 \mathrm{~g}$ ), exactly as ibuprofen + lysine was given. The lysine control animals thus received $16 \mathrm{mg} / \mathrm{kg} \mathrm{BW}$ of lysine, a dose 10 times that given to the animals of group III. The preparation of the animals, the surgery, and the equilibration, control, and experimental periods were exactly as in the animals of groups I-III.

Analytical procedures. Urine volumes were determined gravimetrically and blood gas determinations were performed with a pH/blood analyzer (Gas Analyzer 248, Corning, Essex, U.K.). The automatic Wright anthrone (22) and the Bratton and Marshall (23) methods were used for the determination of inulin and PAH concentrations, respectively (AutoAnalyzer II, Bran \& Luebbe, Norderstedt, Germany). Sodium and potassium were measured by flame photometry (Flame Photometer 943, Instrumentation Laboratory, Lexington, MA, U.S.A.). The plasma protein concentration was estimated refractometrically (TS-meter, American Optical, Buffalo, NY, U.S.A.).

Data analysis. Cin and СРАн were calculated from standard formulae. For the calculation of RPF, a correction was made for the Еран. For the control periods an Еран of 0.55 was used. This is a mean value encountered in our laboratory in experi- 
ments with normoxemic newborn rabbits (24). For the calculation of RPF during the experimental periods we used the mean values of Еран that were obtained in the various animal groups as follows: group I ( $0.02 \mathrm{mg} / \mathrm{kg} \mathrm{BW}$ ibuprofen $), n=$ 10, Еран: $0.43 \pm 0.04$; group II ( $0.02 \mathrm{mg} / \mathrm{kg}$ BW ibuprofen $)$, $n=13$, Еран: $0.50 \pm 0.02$; group III ( $2 \mathrm{mg} / \mathrm{kg} \mathrm{BW}$ ibuprofen), $n=8$, Еран: $0.43 \pm 0.04$; lysine-control experiments (without ibuprofen), $n=8$, ЕрАн: $0.44 \pm 0.03$. The other variables were determined with the following equations: $F F=$ GFR/RPF; $\mathrm{RBF}=\mathrm{RPF} /(1-\mathrm{Htc}) ; \mathrm{RVR}=\mathrm{MAP} / \mathrm{RBF}$.

Statistical analysis. The data for the control and experimental periods are given as the mean \pm SEM of the two 30-min urine collections. The statistics were calculated on the basis of the individual, absolute data. Differences within each group of animals were established by Fishers paired least-significant difference test for repeated measurements (ANOVA, Abacus Concepts Inc., Berkeley, CA, U.S.A.). Comparisons between groups were analyzed by the unpaired $t$ test or by factorial ANOVA, as required. A $p<0.05$ was considered statistically significant.

\section{RESULTS}

Table 1 summarizes the variables indicating the general status of the newborn animals throughout the experiments. MAP, $\mathrm{pH}$, and $\mathrm{PaO}_{2} / \mathrm{PaCO}_{2}$ did not change significantly from the control values in any of the three animal groups. HR changed after the administration of $2 \mathrm{mg} / \mathrm{kg} \mathrm{BW}$ of ibuprofen (group III), whereas the hematocrit and the plasma protein levels fell only slightly, albeit significantly, after the administration of ibuprofen in all three animal groups. These are recurrent findings in the neonatal animal experiments as a result of blood sampling. The renal functional responses to i.v. ibuprofen in the three animal groups are given in Table 2 (absolute data) and Figure 1 (percentage changes). The baseline values for the measured and calculated renal functional parameters were comparable for all three animal groups. After the i.v. administration of ibuprofen, UV fell significantly in animals of groups II and III, but not in those of group I, receiving the lowest dose of ibuprofen (Table 2). There was a clear tendency to a reduction in absolute UVNa, significant only in the animals of group III $(p<0.05)$. GFR fell in all animal groups. The fall was $-13.5 \pm 4.6 \%$ in the animals of group I $(0.02 \mathrm{mg} / \mathrm{kg} \mathrm{BW}$ of ibuprofen $),-32.1 \pm 6.0 \%$ in group II $(0.2 \mathrm{mg} / \mathrm{kg} \mathrm{BW})$, and $-35.8 \pm 4.1 \%$ in group III (2 $\mathrm{mg} / \mathrm{kg} \mathrm{BW}$ ), a dose-dependent effect (Fig. 1). RBF did change significantly in all animals groups: $-15.4 \pm 5.8 \%$ (group I),
$-32.0 \pm 5.4 \%$ (group II), and $-36.4 \pm 2.5 \%$ in group III. FF remained stable in the animals of groups I and II but decreased significantly in group III (I: $+1.8 \pm 6.2 \%$; II: $-1.8 \pm 2.9 \%$; III: $-16.7 \pm 2.5 \%)$. RVR rose in all three animal groups, very significantly $(p<0.001)$ in groups II and III (I: $+19.6 \pm 10.3$; II: $+57.9 \pm 13.2 \%$; III: $+61.2 \pm 10.1$ ) (Fig. 1). After the i.v. administration of lysine (16 mg/kg BW) to eight newborn rabbits, no significant changes in MAP and the renal parameters (UV, GFR, RBF, RVR) were observed (Table 3).

\section{DISCUSSION}

NSAID are used extensively, particularly in the adult population. Most NSAID cause nonspecific inhibition of the prostanoids, although their relative effects on COX-1 or COX-2 may differ in various settings. In addition to the established nonspecific NSAID, newer selective COX-1 or COX-2 inhibitors are now available. The side effects of all these compounds are well recognized and have been the subject of two recent clinical studies in adults $(25,26)$. The main adverse effects of NSAID pertain to gastrointestinal and hematologic toxicity, whereas all these drugs, albeit in different degrees, are vasoactive and affect normal blood flow in a variety of organ systems such as the brain, the mesenteric vascular bed, the ovaries, and the kidneys. In normal, healthy adults the effects of NSAID on renal perfusion are, however, rather limited. The most severe adverse renal effects of NSAID are observed when these drugs are given to individuals with compromised renal function (26). In this respect, the adult with renal impairment seems to react to this group of therapeutic agents much as the term and, in particular, the premature neonate and the unborn fetus. When the pregnant mother receives a NSAID for a basic maternal disorder or in the later stages of gestation for the prevention and treatment of premature labor, the fetus is exposed to these PG-synthesis inhibitors in utero, inasmuch as the NSAID rapidly pass the placental barrier. These drugs interfere with normal nephrogenesis, which may lead to irreparable renal damage. This effect seems to be predominantly due to the inhibition of COX-2, at least in mice and rats $(8-10,27)$. In addition, the fetus may also have a renal vasoactive response with reduction of urinary output and oligohydramnios. After birth, renal failure may ensue $(10,11)$. Recently, the intrauterine exposure to the selective COX-2 inhibitor nimesulide was reported to be associated with neonatal end-stage renal failure (12).

The healthy newborn, and in particular the premature infant, have a precariously low GFR that is maintained by a very

Table 1. The effects of i.v. ibuprofen on MAP, HR, and blood gas variables in three groups of newborn rabbits

\begin{tabular}{|c|c|c|c|c|c|c|c|c|}
\hline Group & Period & $\begin{array}{c}\text { MAP } \\
(\mathrm{mm} \mathrm{Hg})\end{array}$ & $\begin{array}{c}\text { HR } \\
\text { (per min) }\end{array}$ & Htc $(\%)$ & Prot $(\mathrm{g} / \mathrm{L})$ & $\begin{array}{c}\mathrm{PaO}_{2} \\
(\mathrm{~mm} \mathrm{Hg})\end{array}$ & $\begin{array}{c}\mathrm{PaCO}_{2} \\
(\mathrm{~mm} \mathrm{Hg})\end{array}$ & $\mathrm{pH}$ \\
\hline \multirow[t]{2}{*}{ I. Ibuprofen $0.22 \mathrm{mg} / \mathrm{kg}$} & $\mathrm{C}$ & $31.9 \pm 0.7$ & $276 \pm 8$ & $0.28 \pm 0.01$ & $27.5 \pm 1.3$ & $126.6 \pm 6.8$ & $35.0 \pm 0.8$ & $7.53 \pm 0.01$ \\
\hline & E & $31.3 \pm 0.7$ & $273 \pm 9$ & $0.27^{*} \pm 0.01$ & $25.7^{*} \pm 1.0$ & $127.2 \pm 4.9$ & $34.8 \pm 0.7$ & $7.50 \pm 0.01$ \\
\hline II. Ibuprofen $0.2 \mathrm{mg} / \mathrm{kg}$ & E & $31.7 \pm 1.4$ & $268 \pm 7$ & $0.31 * \pm 0.01$ & $27.8 \dagger \pm 1.5$ & $121.2 \pm 3.7$ & $34.9 \pm 0.5$ & $7.51 \pm 0.01$ \\
\hline \multirow{2}{*}{ III. Ibuprofen 2 mg/kg } & $\mathrm{C}$ & $28.5 \pm 1.3$ & $281 \pm 7$ & $0.29 \pm 0.02$ & $30.8 \pm 3.7$ & $120.2 \pm 5.0$ & $35.3 \pm 0.6$ & $7.53 \pm 0.01$ \\
\hline & $\mathrm{E}$ & $28.6 \pm 2.0$ & $271 \dagger \pm 7$ & $0.28^{*} \pm 0.02$ & $27.6^{*} \pm 2.6$ & $122.2 \pm 4.5$ & $33.7 \pm 0.8$ & $7.52 \pm 0.01$ \\
\hline
\end{tabular}

Values are means $\pm \mathrm{SE}$.

$* p<0.05, \dagger p<0.01$ vs control period of the same group of animals. 
Table 2. The effects of i.v. ibuprofen on renal function in three groups of newborn rabbits

\begin{tabular}{|c|c|c|c|c|c|c|c|}
\hline Group & Period & $\begin{array}{c}\mathrm{UV} \\
(\mathrm{mL} / \mathrm{kg} / \mathrm{min})\end{array}$ & $\begin{array}{c}\text { UVNa } \\
(\mathrm{mmol} / \mathrm{kg} / \mathrm{min})\end{array}$ & $\begin{array}{c}\text { GFR } \\
(\mathrm{mL} / \mathrm{kg} / \mathrm{min})\end{array}$ & $\begin{array}{c}\mathrm{RBF} \\
(\mathrm{mL} / \mathrm{kg} / \mathrm{min})\end{array}$ & FF (\%) & $\begin{array}{c}\text { RVR } \\
(\mathrm{mm} \mathrm{Hg} / \mathrm{mL} / \mathrm{kg} / \mathrm{min})\end{array}$ \\
\hline \multirow[t]{2}{*}{ I. Ibuprofen $0.02 \mathrm{mg} / \mathrm{kg}$} & $\mathrm{C}$ & $0.075 \pm 0.003$ & $1.88 \pm 0.71$ & $1.94 \pm 0.11$ & $16.5 \pm 1.1$ & $17.1 \pm 1.2$ & $2.11 \pm 0.17$ \\
\hline & $\mathrm{E}$ & $0.071 \pm 0.006$ & $1.45 \pm 0.57$ & $1.66^{*} \pm 0.10$ & $13.9^{*} \pm 1.1$ & $16.9 \pm 0.9$ & $2.43 \pm 0.21$ \\
\hline II. Ibuprofen $0.2 \mathrm{mg} / \mathrm{kg}$ & $\mathrm{E}$ & $0.046 \div \pm 0.004$ & $0.75 \pm 0.10$ & $1.30 \ddagger \pm 0.10$ & $12.4 \div \pm 1.1$ & $15.6 \pm 0.5$ & $2.90 \div \pm 0.27$ \\
\hline \multirow{2}{*}{ III. Ibuprofen 2 mg/kg } & $\mathrm{C}$ & $0.079 \pm 0.007$ & $2.58 \pm 0.49$ & $2.02 \pm 0.16$ & $17.7 \pm 1.5$ & $16.6 \pm 0.8$ & $1.72 \pm 0.13$ \\
\hline & $\mathrm{E}$ & $0.048 \dagger \pm 0.003$ & $1.14 * \pm 0.26$ & $1.29 \ddagger \pm 0.13$ & $11.3+ \pm 1.1$ & $13.7 \ddagger \pm 0.5$ & $2.74 \$ \pm 0.22$ \\
\hline
\end{tabular}

Values are means $\pm \mathrm{SE}$.

$* p<0.05, \dagger p<0.01, \ddagger p<0.001 v s$ control period of the same group of animals.

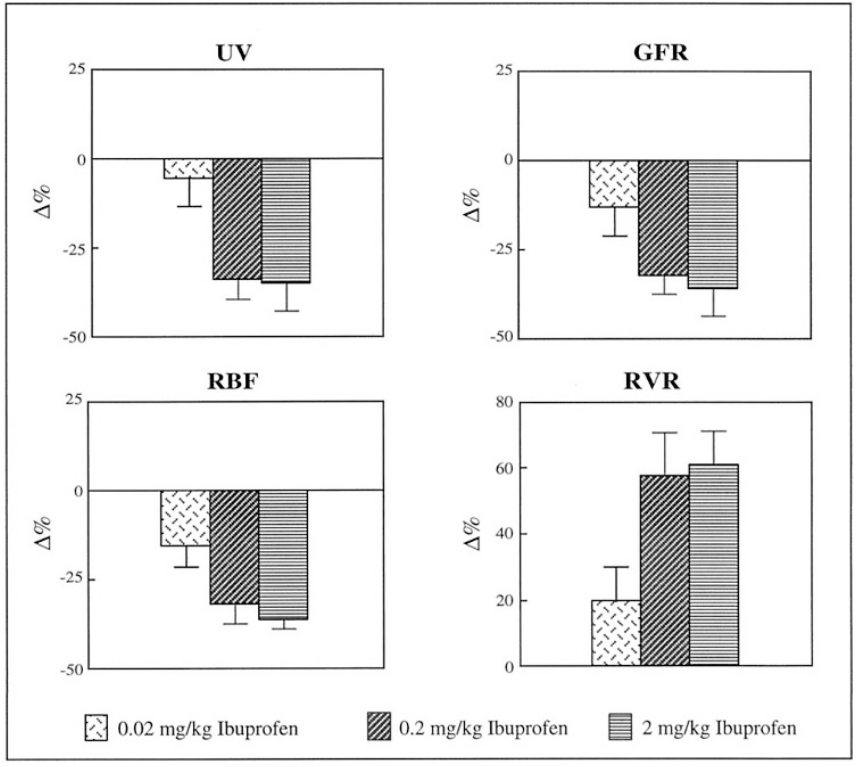

Figure 1. The percentage changes $(\Delta \%)$ in UV, GFR, RBF, and RVR observed in three groups of neonatal rabbits after the i.v. administration of 0.02 , 0.2 , and $2 \mathrm{mg} / \mathrm{kg} \mathrm{BW}$ of ibuprofen.

delicate balance of vasoconstrictor (angiotensin II, endothelin) and vasodilatory (atrial natriuretic peptide, adrenomedullin, the kallikein-kinin system, nitric oxide, PG) forces. The most important vasoconstrictor force is angiotensin II, whereas the PG $\left(\mathrm{PGE}_{2}, \mathrm{PGI}_{2}\right)$ are the main vasodilators, both abundantly present in the neonatal period (28). PG promote renin secretion and thus angiotensin II formation (29), whereas this process is blocked by PG-synthesis inhibitors such as indomethacin and ibuprofen. The administration of a PG-synthesis inhibitor such as ibuprofen reduces renal vasodilatation, resulting in greatly increased vasoconstrictor activity, which is already very high. That is indeed what was found in the experiments described in the present study. Intravenous administration of ibuprofen $(0.02-2 \mathrm{mg} / \mathrm{kg} \mathrm{BW})$ to newborn rabbits caused a significant increase in RVR and a fall in RBF and GFR. This was accompanied by a reduction in UV and UVNa, whereas MAP remained unchanged. There was a definite dose-dependent response between 0.02 and $0.2 \mathrm{mg} / \mathrm{kg} \mathrm{BW}$ of ibuprofen; little further change was seen with an additional 10-fold increase of the dose (Fig. 1). The response of the neonatal rabbit kidney to i.v. ibuprofen is not unexpected. Previous neonatal animal studies from our laboratory showed a similar pattern after the i.v. administration of aspirin or indomethacin. In the study by Ballèvre et al. (16), i.v. indomethacin (2 mg/kg BW) induced a rise in RVR ( $+55 \%$ ), a reduction in RBF and GFR (both approximately $-45 \%$ ), with significant oliguria (UV: $-39 \%$; $p<0.001)$. Aspirin caused a very rapid reversible vasoconstriction in 1-wk-old rabbits, evidenced by a steep rise in RVR $(+153 \%)$ and a fall in RBF and GFR of $-52 \%$ and $-34 \%$, respectively (data submitted for publication). The same dose (per $\mathrm{kg} \mathrm{BW}$ ) of i.v. aspirin had a very attenuated effect in 12-wk-old (young adult) animals. This observation reinforces the notion that neonatal animals (and probably human neonates) are far more sensitive to the administration of NSIAD than their adult counterparts. It is tempting to speculate that this is due to the high basic activity of the various vasoactive forces in the newborn kidney, resulting in an overriding pronounced vasoconstrictor state

We assume that these renal hemodynamic responses of neonatal (and young adult) rabbits to acute i.v. doses of NSAID are mainly due to nonspecific inhibition of the renal COX. We do not have proof that this is indeed the case, inasmuch as we have not ourselves studied this aspect of neontal renal (pathophysiology). Nor is this developmental aspect of the renal COX the subject of the present paper. The localization or distribution of COX-1 and -2 in the human kidney seems to be different from that in the rat and there are differences in specific COX expression between fetal and adult human kidneys. According to Kömhoff et al. (30), COX-1 is primarily expressed in podocytes and collecting duct cells of fetal human kidneys, increasing markedly from the subcapsular to the juxtamedullary cortical region. COX-2 appears toward the end of gestation in fetal glomerular podocytes. In the adult human kidney COX-2 was found in endothelial cells and the vascular wall of artery and veins as well as podocytes. According to Kömhoff et al. COX-1 may be involved in (angio)glomerulogenesis whereas COX-2 seems to be of prime importance for renal perfusion and glomerular hemodynamics (30).

The presently available clinical and experimental data on the hemodynamic effects of NSAID in the newborn period relate more to the cerebral than to the renal circulation. Many excellent studies in experimental animals (mostly newborn piglets) and human newborns (often premature) on the effect of NSAID on cerebral blood flow have shown that inhibition of PG synthesis does not necessarily explain the hemodynamic responses to NSAID. These cerebral perfusion data may, however, not directly apply to a situation in which NSAID affect the rapidly changing postnatal renal perfusion. On the other hand, it may well be that the ultimate renal response to PG inhibition in the kidney, just as in the brain, depends on many 
Table 3. The effects of i.v. lysine on renal function in newborn rabbits

\begin{tabular}{cccccrr}
\hline & Period & $\begin{array}{c}\text { MAP } \\
(\mathrm{mm} \mathrm{Hg})\end{array}$ & $\begin{array}{c}\mathrm{UV} \\
(\mathrm{mL} / \mathrm{kg} / \mathrm{min})\end{array}$ & $\begin{array}{c}\mathrm{GFR} \\
(\mathrm{mL} / \mathrm{kg} / \mathrm{min})\end{array}$ & $\begin{array}{c}\mathrm{RBF} \\
(\mathrm{mL} / \mathrm{kg} / \mathrm{min})\end{array}$ & $\begin{array}{c}\mathrm{RVR} \\
(\mathrm{mm} \mathrm{Hg} / \mathrm{mL} / \mathrm{kg} / \mathrm{min})\end{array}$ \\
\hline Lysine $(1.6 \mathrm{mg} / \mathrm{kg} \mathrm{BW})$ & $\mathrm{C}$ & $32.3 \pm 1.62$ & $0.079 \pm 0.014$ & $1.67 \pm 0.22$ & $15.94 \pm 1.5$ & $2.15 \pm 0.15$ \\
& $\mathrm{E}$ & $29.9 \pm 1.24$ & $0.078 \pm 0.011$ & $1.48 \pm 0.25$ & $15.6 \pm 1.7$ & $2.08 \pm 0.27$ \\
\hline
\end{tabular}

Values are means $\pm \mathrm{SE}$.

other vasoactive mechanisms, beyond those regulated by COX-1 and -2. For a thorough discussion on this subject, the reader is referred to the literature $(5,31-36)$. To complicate matters, it is now well known that chloride plays a role in the various responses to $\mathrm{COX}$ inhibition in the kidney of the isolated, adult rat (37).

Perhaps the most important observation concerns the difference between neonatal and adult individuals. For example, the infusion of PG to newborn piglets causes cerebral vasoconstriction, whereas these same agents have a prominent vasodilatory action in adults (36). In our own laboratory, the kidneys of newborn rabbits showed the same paradoxical vasoconstrictive response to the infusion of the vasodilator agents $\mathrm{PGE}_{2}$ and prostacyclin $\left(\mathrm{PGI}_{2}\right)$ (unpublished data). One wonders if this may relate to the differences in the location of COX-1 and -2 between adult and fetal human kidneys, as outlined above (30).

The present experiments were not designed to evaluate the various pathophysiologic pathways that govern the hemodynamic responses to PG-synthesis inhibition in different organ systems. The animal studies reported here were initiated because we were struck by various reports that indicated that ibubrofen is less vasoactive in the brain, the gastrointestinal tract, and the kidneys than indomethacin $(5,6,18-20,38,39)$. It is interesting to go back twenty years to the studies by Feigen et al. (38) in adult dogs. These experiments showed that indomethacin produced severe acute vasoconstriction of the mesenteric vessels whereas ibuprofen did not (38). These were, as already mentioned, adult animals, but much of the literature shows the same pattern in infancy. In contrast, the main finding of our studies, as outlined above, was that newborn rabbits react to i.v. ibuprofen more or less in the same manner as found previously with the i.v. administration of indomethacin or aspirin. In our laboratory, all tested NSAID caused a reduction in RBF and GFR with a very significant rise in RVR. Not only total RBF is affected by PG-synthesis inhibition but probably also intrarenal blood flow distribution. This may be associated with a delay in the physiologic, postnatal shift of blood from the deep cortical juxtamedullary nephrons to the nephrons in the outer cortex. In other words, newborns exposed to NSAID may well have a persistent, or redirected, predominantly deep cortical juxtamedullary nephron perfusion. These juxtamedullary nephrons are the most mature water and salt conserving nephrons, a fact that may explain the fall in UV and the compensatory increase in tubular reabsorption of sodium (or the fall in UVNa). Another homeostatic aspect of PG-synthesis inhibition is up-regulation of the renal aquaporins, producing an increase in free water reabsorption in the collecting duct (40).

We are pediatricians and do not treat newborn rabbits but infants and children. The major question, therefore, is whether the above described laboratory findings have any clinical relevance. The first conclusion should be that when NSAID are given to neonates, the renal function has to be followed very carefully, even though we know that the renal changes after indomethacin administration to adults and neonates are often reversible. When renal function declines - at this young age generally measured by an increase in plasma creatinine concentrations - the administration of NSAID should, in principle, be stopped. There is, however, one pitfall: plasma creatinine levels immediately after birth rise due to temporary tubular reabsorption of creatinine, especially in preterm infants (41). When NSAID are administered during gestation, the amount of amniotic fluid should be determined regularly by ultrasonography. In regard to the possible toxicity of both indomethacin and ibuprofen, in the neonate and certainly in the premature infant, these drugs have longer half lives than later in childhood or in adulthood (34). Indomethacin has been shown to have clinically important renal side effects, both in acute dosing of three i.v. boluses of $0.2 \mathrm{mg} / \mathrm{kg} \mathrm{BW}$ as well as on more prolonged administration of $0.1 \mathrm{mg} / \mathrm{kg} \mathrm{BW}$ per day for 5-6 d to premature infants (42). Diuretic therapy has been claimed by some to reduce the renal side effects of indomethacin (43), though in premature babies this did not prove to be the case (44). Ibuprofen had few significant renal side effects when given in one or three i.v doses $(10 \mathrm{mg} / \mathrm{kg} \mathrm{BW}$ only versus $10+5+5 \mathrm{mg} / \mathrm{kg} \mathrm{BW}$ ) starting $3 \mathrm{~h}$ after birth in premature babies, though the renal function tests performed were not very sophisticated (18). Van Overmeire et al. indicated that one i.v. dose of $10 \mathrm{mg} / \mathrm{kg} \mathrm{BW}$ ibuprofen followed with two daily doses of $5 \mathrm{mg} / \mathrm{kg} \mathrm{BW}$ had less renal side effects than three daily i.v. pulses of indomethacin in a dose of $0.2 \mathrm{mg} / \mathrm{kg} \mathrm{BW}$ (19). These authors conclude that ibuprofen is less nephrotoxic in the newborn than indomethacin only on the basis of comparing the decrease in urine output and the rise in plasma creatinine between patients receiving these two drugs. True renal function was not measured.

It is difficult to compose a definite summary of the available clinical data regarding the renal toxicity of indomethacin and ibuprofen. In the absence of large, carefully controlled trials on the comparison of these two drugs, it seems that one must rely on animal studies, as described above. On the basis of these studies, covering a wide range of i.v. dosages, it is highly improbable that one can expect ibuprofen in the newborn period to have less renal side effects than indomethacin. Indomethacin and ibuprofen act in a similar fashion. Both agents are nonselective inhibitors of tissue COX-1 and -2 , which forms the basis for their action in pharmacologically closing a hemodynamic significant PDA, unfortunately with side effects in other vascular beds. At this point in time, there is little data 
on the effect of selective COX inhibitors on closure of PDA.

In conclusion, the above animal experiments show that in the neonatal period ibuprofen does not have significantly less renal side effects than indomethacin, as has been claimed.

Acknowledgments. The authors thank Mrs. Michèle Thonney Viani and Mrs. Monique Julita for their contribution in the laboratory.

Addendum. Since the submission of this manuscript the New Eng J Med published an "Early Release Article" on the web in which Drs. Overmeire et al. reiterate that ibuprofen given to premature infants has less renal side-effects than indomethacin. The article appears in print on Sept. 7, 2000.

\section{REFERENCES}

1. Friedman WF, Hirschklau MJ, Printz MP, Pitlick PT, Kirkpatrick SE 1976 Pharmacologic closure of patent ductus arteriosus in the premature infant. N Engl J Med 295:526-529

2. Heymann MA, Rudolph AM, Silverman NH 1976 Closure of the ductus arteriosus in premature infants by inhibiton of prostaglandin synthesis. N Engl J Med 295:530-533

3. Van der Heijden AJ, Tibboel D, Fetter WPF, Wolff E 1986 Intrauterine exposure to indomethacin. Eur J Pediatr 145:579

4. Van der Heijden AJ, Provoost AP, Nauta J, Grose W, Oranje WA, Wolff E, Sauer PJJ 1988 Renal functional impairment in preterm neonates related to intrauterine indomethacin exposure. Pediatr Res 24:644-648

5. Speziale MV, Allan RG, Henderson CR, Barrington KJ, Finer NN 1999 Effects of ibuprofen and indomethacin on the regional circulation in newborn piglets. Bio Neonate 76:242-252

6. Pezzati M, Vangi V, Biagiotti R, Bertini G, Cianciulli D, Rubaltelli F 1999 Effect of indomethacin and ibuprofen on mesenteric and renal blood flow in preterm infants with patent ductus arteriosus. J Pediatr 135:733-738

7. Dinchuk JE, Gar BD, Contel NR, Eng VH, Collins JR, Czerniak PM, Gorry S, Trzakos J 1995 Renal abnormalities and an altered inflammatory response in mice lacking cylooxygenase II. Nature 378:406-409

8. Zhang M-Z, Wang J-L, Cheng H-F, Harris RC, McKanna JA 1997 Cyclooxygenase-2 in rat nephron development. Am J Physiol 273:F994-F1002

9. Kömhoff M, Wang J-L, Cheng H-F, Langenbach R, McKanna JA, Harris RC, Brewer MR 2000 Cyclogenases-2-selective inhibitors impair glomerulogenesis and renal cortical development Kidney Int 57:414-422

10. Kaplan BS, Restaino I, Raval DS, Gottlieb RP, Bernstein J 1994 Renal failure in the neonate associated with in utero exposure to non-steroidal anti-inflammatory agents. Pediatr Nephrol 8:700-704

11. Van der Heijden AJ, Calus C, Narcy F, Bavoux F, Delezoide A-L, Gubler M-C 1994 Persistent anuria, neonatal death, and renal microcystic lesions after prenatal exposure to indomethacin. Am J Obstet Gynecol 171:617-623

12. Peruzzi L, Gianoglio B, Porcellini MC, Coppo R 1999 Neonatal end-stage renal failure associated with maternal ingestion of cyclo-oxygenase-type-1 selective inhibitor nimesulide as tocolytic. Lancet 354:1615

13. Halliday HL, Hirata T, Brady JP 1979 Indomethacin therapy for large patent ductus arteriosus in the very low birth weight infant: results and complications. Pediatrics $64: 154-159$

14. Gersony WM, Peckham GJ, Ellison RC, Miettinen OS, Nadas AS 1983 Effects of indomethacin in premature infants with patent ductus arteriosus: results of a national collaborative study. J Pediatr 102:895-906

15. Clyman RI 1996 Recommendations for the postnatal use of indomethacin: an analysis of four seperate treatment startegies. J Pediatr 128:601-607

16. Ballèvre L, Thonney M, Mosig D, Guignard JP 1996 Inhibition of prostaglandin synthesis by aspririn during the early neonatal period. Pediatr Nephrol 10:C124(abstr)

17. Duarte-Silva M, Gouyon JB, Guignard JP 1986 Renal effects of indomethacin and dopamine in newborn rabbits. Kidney Int 30:455-456
18. Varvarigou A, Bardin CL, Beharry K, Chemtob S, Papageorgiou A, Aranda JV 1996 Early ibuprofen administration to prevent patent ductus arteriosus in premature newborn infants. JAMA 275:539-544

19. Van Overmeire B, Follens I, Hartmann S, Creten WL, Van Acker KJ 1997 Treatment of patent ductus arteriosus with ibuprofen. Arch Dis Child 76:F179-F184

20. Patel J, Marks KA, Roberts I, Azzopardi D, Hamilton P, Edwards AD 2000 Randomized double-blind controlled trial comparing the effects of ibuprofen with indomethacin on cerebral hemodynamics in preterm infants with patent ductus arteriosus. Pediatr Res 47:36-42

21. Gouyon JB, Vallotton M, Guignard JP 1987 The newborn rabbit: a model for studying hypoxemia-induced renal changes. Biol Neonate 52:115-120

22. Wright HK, Gann DS 1966 An automatic anthrone method for the determination on inulin in plasma and urine. J Lab Clin Med 67:689-693

23. Bratton AC, Marshall EK 1939 A new coupling component for sulfanilamide determination. J Biol Chem 128:537-550

24. Gouyon JB, Guignard JB 1988 Theophylline prevents the hypoxemia-induced renal hemodynamic changes in rabbits. Kidney Int 33:1078-1083

25. Brater DC 1999 Effects of nonsteroidal anti-inflammatory drugs on renal function: focus on cyclogenase-2-selective inhibition. Am J Med 107(6A):65S-71S

26. Whelton A 1999 Nephrotoxicity of nonsteroidal anti-inflammatory drugs: physiologic foundations and clinical implications. Am J Med 106(5B):13S-24S

27. Morham SG, Langenbach R, Loftin CD, Tiano HF, Vouloumanos N, Jenette JC, Mahler JF, Kluckman KD, Ledford A, Lee CA, Smities O 1995 Prostalandin synthase 2 gene disruption causes severe renal pathology in the mouse. Cell 83:473-482

28. Toth-Heyn P, Drukker A, Guignard JP 2000 The neonatal stressed kidney: from pathophysiology to clinical management. Pediatr Nephrol 14:227-239

29. Jensen BL, Schmid C, Kurtz A 1996 Prostaglandins stimulate renin secretion and renin mRNA in mouse renal juxtaglomerular cells. Am J Physiol 271:F659-F669

30. Kömhoff M, Göne H-J, Klein T, Syberth HW, Nüsing HW 1997 Localization of cyclooxygenase- 1 and -2 in adult and fetal human kidney: implication for renal function. Am J Physiol 272:F460-F468

31. Chemtob S, Laudignon N Beharry K, Rex J, Wolfe, Varma DR, Aranda JV 1990 Effects of prostaglandins and indomethacin on cerebral blood flow and cerebral oxygen consumption of concious newborn piglets. Dev Pharmacol Ther 14:1-14

32. Chemtob S, Beharry K, Barna T, Varma DR, Aranda JV 1991 Differences in the effects in the newborn piglet of various nonsteroidal antiinflammatory drugs on cerebral blood flow but not on cerebrovascular prostaglandins. Pediatr Res 30:106111

33. Malcolm DM, Segar JL, Robillard JE, Chemtob S 1993 Indomethacin compromises hemodynamics during positive pressure ventilation, independently of prostanoids. J Appl Physiol 74:1672-1678

34. Aranda JV, Varvarigou A, Beharry K, Bansal R, Bardin C, Modanlou H, Papageorgiou A, Chemtob S 1997 Pharmacokinetics and protein binding of intravenous ibuprofen in the premature newborn infant. Acta Paediatr 86:289-293

35. Laudignon N, Chemtob S, Bard H, Aranda JV 1988 Effect of indomethacin on the cerebral blood flow velocity of premature newborns. Biol Neonate 54:254-262

36. Chemtob S, Beharry K, Rex J, Varma DR, Aranda JV 1990 Prostanoids determine the range of cerebral blood flow autoregulation of newborn piglets. Stroke 21:777-784

37. Yin K, McGiff JC, Bell-Quilley P 1995 Role of chloride in the variable response of the kidney to cyclooxygenase inhibition. Am J Physiol 268:F561-F568

38. Feigen LP, King LW, Ray J, Beckett W, Kadowitz PJ 1981 Differential effects of ibuprofen and indomethacin in the regional circulation of the dog. J Pharmacol Exp Ther 219:679-684

39. Mosca F, Bray M, Lattanzio M, Fumagalli M, Tosetto C 1997 Comparative evaluation of the effects of indomethacin and ibuprofen on cerebral perfusion and oxygenation in preterm infants with patent ductus arteriosus. J Pediatr 131:549-554

40. Nielsen S, Kwon TH, Christensen BM, Promeneur D, Frokiaer J, Marples D 1999 Physiology and pathophysiology of renal aquaporins. J Am Soc Nephrol 10:647-663

41. Matos P, Duarta Silva M, Drukker A, Guignard JP 1998 Creatinine reabsorption by the newborn rabbit kidney. Pediatr Res 44:939-941

42. Gouyon JB, Chouchane M, Françoise M 1994 Effets rénaux d'un traitement prolongé par indométacine chez le prématuré Arch Pédiatr 1:894-897

43. Yeh TF, Wilks A, Singh J, Betkerur M, Lilien L, Pildes RS 1982 Furosemide prevents the renal side effects of indomethacin therapy in premature infants with patent ductus arteriosus. J Pediatr 101:433-437

44. Romagnoli C, Zecca E, Papacci P, de Carolis MP, Giannini P, Gallini F, Tortorolo G 1997 Furosemide does not prevent the indomethacin-induced renal side-effects in preterm infants. J Pharmacol Exp Ther 62:181-186 